Article

\title{
Possibility of Calcium Oxide from Natural Limestone Including Impurities for Chemical Heat Pump
}

\author{
LanXin Lai ${ }^{1}$, Toshio Imai ${ }^{2}$, Motohiro Umezu ${ }^{2}$, Mamoru Ishii ${ }^{2}$ and Hironao Ogura ${ }^{1, * \mathbb{D}}$ \\ 1 Graduate School of Science and Engineering, Chiba University, 1-33, Yayoi-cho, Inage, Chiba 263-8552, Japan; \\ lai_lanxin@chiba-u.jp \\ 2 Central Research Laboratory, Taiheiyo Cement Corporation, 2-4-2, Osaku, Sakura 285-8655, Japan; \\ Toshio_Imai@taiheiyo-cement.co.jp (T.I.); Motohiro_Umezu@taiheiyo-cement.co.jp (M.U.); \\ Mamoru_Ishii@taiheiyo-cement.co.jp (M.I.) \\ * Correspondence: hiro_ogura@faculty.chiba-u.jp; Tel.: +81-43-290-3506
}

Received: 24 December 2019; Accepted: 6 February 2020; Published: 12 February 2020

check for updates

\begin{abstract}
Improving energy recycle is an important way to save energy resources and preserve the global environment. Chemical heat pump (CHP) is a technology for saving energy, which utilizes chemical reactions to store thermal energy such as waste heat and solar heat, then release it to provide heat for heating/cooling/refrigeration. For a practical CHP, it is necessary to find cheaper and more stable supply materials. In order to evaluate the possibility of calcium oxide from natural Ofunato natural limestone including impurities, we compare Ofunato limestone with Kawara natural limestone and Garou natural limestone from Japan. These calcium oxides worked as a reactant for $\mathrm{CaO} / \mathrm{H}_{2} \mathrm{O} / \mathrm{Ca}(\mathrm{OH})_{2} \mathrm{CHP}$ by repeated hydration/dehydration reaction cycle experiments in a thermogravimetric analyzer. As a result, Ofunato $\mathrm{CaO}$ exhibits a high hydration reaction rate after decarbonization at $1223 \mathrm{~K}$ for $5 \mathrm{~h}$. The reactivity increased by the repeated hydration reaction although the first hydration rate was low. Furthermore, the sintering of impurities in Ofunato limestone occur easier than that in Kawara limestone with lower impurities. The impurities adhered to the surface of the $\mathrm{CaO}$ particle to make specific surface area of $\mathrm{CaO}$ particle smaller, which could inhibit hydration reaction of $\mathrm{CaO}$ particle. Even if Ofunato limestone contains some impurities, it can be utilized as a raw material for chemical heat pumps.
\end{abstract}

Keywords: chemical heat storage; Ofunato limestone; hydration reaction; $\mathrm{CaO} ; \mathrm{Ca}(\mathrm{OH})_{2} ; \mathrm{CaCO}_{3}$

\section{Introduction}

With the increasing development of the global economy, the utilization of fossil fuels is increasing. Improving energy recycling is an important way to save energy resources and preserve the global environment. Chemical heat pumps (CHPs) are one of such technologies for saving and reusing thermal energy [1]. They can use chemical reactions to store thermal energy such as unused industrial waste heat from factories and solar heat, and release it when needed to provide heat for heating/cooling/refrigerating.

In the past, chemical heat pump dryer (CHPD) systems for ecologically effective utilization of thermal energy in drying were proposed by Ogura et al. [2]. Further, Ogura et al. proposed a stand-alone high-efficiency heating and cooling system using a CHP driven only by solar energy $[3,4]$. In order to improve the fuel efficiency of vehicles by recycling the engine waste heat, Ogura et al. investigated the possibility of waste heat recycle utilization for automobiles by CHP [5].

For chemical heat storage materials, $\mathrm{CaCl}_{2}$ and $\mathrm{H}_{2} \mathrm{O}$ were selected as the reactant and working medium, assuming the utilization of low-grade waste heat [6]. Li et al. investigated the hydration and dehydration reaction of lithium hydroxide $(\mathrm{LiOH})$ for low temperature heat sources [7]. Ryu et al. 
investigated how $\mathrm{LiOH}$-modified $\mathrm{Mg}(\mathrm{OH})_{2}\left(\mathrm{LiOH} / \mathrm{Mg}(\mathrm{OH})_{2}\right)$ could be a potential chemical heat storage material [8].

A CHP is a closed unit and can be one of the next generation heat pump technologies for thermal recycling using chemical heat storage. Chemical heat storage materials have a great influence on the practical use of the CHP. The selection of heat storage material for a CHP depends on the application, temperature range of heat storage unit and whether it can reach the equilibrium line by considering the operation of the CHP. For low temperature heat sources, Ogura et al. studied the CHP using he $\mathrm{CaSO}_{4} / \mathrm{CaSO}_{4} \cdot 1 / 2 \mathrm{H}_{2} \mathrm{O}$ reversible reaction that stores under $373 \mathrm{~K}$ level thermal energy, and releases the same level of hot heat and $273 \mathrm{~K}$ level cooling heat [9]. Furthermore, Esaki et al. proposed a chemical heat pump chiller with a $\mathrm{SrBr}_{2}$ hydration reaction system for utilization of waste heat (353-373 K) $[10,11]$. Kato et al. studied the kinetics of the hydration of magnesium oxide under 373-423 K [12]. It was shown that magnesium oxide can be one of materials to store low-medium temperature heat for CHPs. For high temperature heat sources, Tomari et al. showed that steam reforming and methanation could be used for storing steel manufacturing heat (873-1173 K) by CHP [13].

Although various heat storage materials can be used in $\mathrm{CHP}$, for the high temperature range we use calcium oxide $(\mathrm{CaO})$ made from natural limestone $\left(\mathrm{CaCO}_{3}\right)$, which is widely distributed in Japan [14]. This is because $\mathrm{CaO}$ from limestone is low cost, safe to use and it has a high storage density $(1.86 \mathrm{MJ} / \mathrm{kg})$. For a practical CHP, it is necessary to find cheap and more stable supply materials. Therefore, in our laboratory, Zhang et al. studied the hydration reaction rates model of various sized $\mathrm{CaO}$ samples from natural Hiroshima limestone produced in Hiroshima/Okayama Prefecture, Japan, and considered the effects of the particle size and the heat/mass transfer resistance [15]. Due to the low durability of Hiroshima limestone, Ogura et al. examined $\mathrm{CaO}$ from other limestones (Kawara $\mathrm{CaO}$ and $\mathrm{Garou} \mathrm{CaO}$ ) and compared the hydration reaction characteristics [16]. They showed that $\mathrm{CaO}$ from Garou limestone can be used as a practical material for CHP due to its relatively high strength and reactivity. Kikuchi et al. showed that $\mathrm{CHP}$ unit with low-purity Garou $\mathrm{CaO}$, which has more impurities than Ofunato $\mathrm{CaO}$, had a better performance than $\mathrm{CHP}$ units with high-purity Kawra $\mathrm{CaO}$ [17]. The reaction rates of low-purity Garou $\mathrm{CaO}$ in repeated experiments became higher than those of the high-purity Kawara $\mathrm{CaO}$ reaction.

In previous studies [18], we demosntrated that Kawara $\mathrm{CaO}$ limestone with high purity had high hydration reaction characteristic. However, common limestone, which is widely distributed throughout Japan, contains impurities such as quartz, clay minerals, etc. The effects of these impurities on $\mathrm{CaO}$ reactivity for $\mathrm{CHP}$ are not clear. Therefore, we chose a new sample $\mathrm{CaO}$ from Ofunato limestone, which has relatively high levels of impurities. The objectives of this study were thus to evaluate the practicability of Ofunato limestone as a chemical heat pump material by comparing Ofunato limestone with Kawara limestone and Garou limestone, and to examine the effects of the impurities in Ofunato $\mathrm{CaO}$ on the hydration reaction.

\section{Operating Principle of $\mathrm{CaO} / \mathrm{H}_{2} \mathrm{O} / \mathrm{Ca}(\mathrm{OH})_{2}$ Chemical Heat Pump}

A CaO/H $\mathrm{H}_{2} \mathrm{O} / \mathrm{Ca}(\mathrm{OH})_{2}$ chemical heat pump is theoretically based on the following equations:

$$
\begin{gathered}
\mathrm{CaO}_{(\mathrm{s})}+\mathrm{H}_{2} \mathrm{O}_{(\mathrm{g})} \rightleftarrows \mathrm{Ca}(\mathrm{OH})_{2(\mathrm{~s})}+104.2 \mathrm{~kJ} / \mathrm{mol} \\
\mathrm{H}_{2} \mathrm{O}_{(\mathrm{g})} \rightleftarrows \mathrm{H}_{2} \mathrm{O}_{(\mathrm{l})}+43.9 \mathrm{~kJ} / \mathrm{mol}
\end{gathered}
$$

Figure 1 shows the operating principle of a $\mathrm{CaO} / \mathrm{H}_{2} \mathrm{O} / \mathrm{Ca}(\mathrm{OH})_{2}$ chemical heat pump. In the heat storing step, when heat $\mathrm{Q}_{\mathrm{H}}$ is supplied to the high temperature reactor, the heat $\mathrm{Q}_{\mathrm{H}}$ is stored in the form of $\mathrm{CaO}_{(\mathrm{s})}$ as thermochemical energy by decomposition of $\mathrm{Ca}(\mathrm{OH})_{2(\mathrm{~s})}$. The released water vapor flows into condenser under low temperature due to the pressure difference between the reactor and condenser. The water vapor condenses and releases the low temperature heat $\mathrm{Q}_{\mathrm{L}}$.

In the heat releasing step, the water vapor flows from evaporator into the reactor by opening a valve due to the pressure difference between reactor and evaporator. The exothermic hydration reaction 
of the reactant $\mathrm{CaO}_{(\mathrm{s})}$ takes place and releases $\mathrm{Q}_{\mathrm{H}}$ in the reactor. In the evaporator, the temperature is cooled down due to the latent heat of water evaporation.

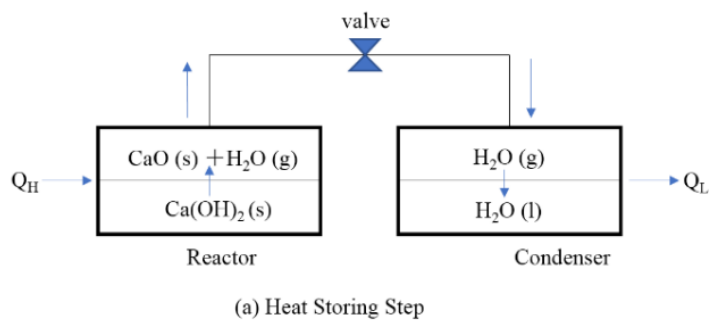

(a)

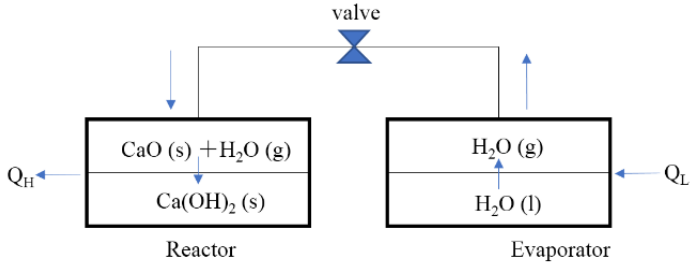

(b) Heat Releasing Step

(b)

Figure 1. Operating principle of chemical heat pump. (a) Heat Storing Step (b) Heat Releasing Step.

In this study, a thermogravimetric analyzer (TGA-51) was used as a reactor connected to the temperature control bath used as an evaporator/a condenser. The experimental unit is a model of CHP, which can store the thermal energy in TGA-51 by dehydration reaction, and release it to provide heat for heating in TGA-51 by hydration reaction.

\section{Sample Materials}

Kawara limestone produced in Fukuoka Prefecture, Japan, Garou limestone produced in Hokkaido Prefecture, Japan, Ofunato limestone produced in Iwate Prefecture, Japan were obtained from the aggregate plants nearby each quarry as raw materials. Thirty $\mathrm{kg}$ of natural limestone were crushed into particles of less than $5 \mathrm{~mm}$ in size by a jaw crusher and mixed homogeneously. To get smaller particles (less than $2 \mathrm{~mm}$ ), pulverization by a steel mortar was repeated. The samples are classified into $710-1000 \mu \mathrm{m} \varphi$ by a sieve, according to the previous studies [15,16]. $10 \mathrm{mg} / 10 \mathrm{~g} / 100 \mathrm{~g}$ limestone were used for the repeated hydration experiments.

Table 1 presents the chemical compositions (mass $\%$ ) of the natural limestone samples. It shows that the purity of Kawara limestone is $99.66 \%$ and that of Ofunato limestone is $96.96 \%$. However, the purity of Garou limestone is $95.01 \%$. The amount of $\mathrm{SiO}_{2}$ in Ofunato limestone is higher (1.26\%) compared to Kawara limestone. The amount of $\mathrm{Fe}_{2} \mathrm{O}_{3}$ and $\mathrm{Al}_{2} \mathrm{O}_{3}$ in Ofunato limestone are also higher than that in Kawara limestone and Garou limestone. The amount of $\mathrm{MgO}$ in Garou limestone is the highest $(2.38 \%)$ of all them.

Table 1. Chemical compositions (mass \%) of different natural limestone samples. (measured by a ZSX Primus II Scanning X-ray fluorescence analyzer, Rigaku, Japan).

\begin{tabular}{cccccccccccc}
\hline Sample & Ig.Ioss & $\mathrm{SiO}_{2}$ & $\mathrm{Al}_{2} \mathrm{O}_{3}$ & $\mathrm{Fe}_{2} \mathrm{O}_{3}$ & $\mathrm{CaO}$ & $\mathrm{MgO}$ & $\mathrm{SO}_{3}$ & $\mathrm{~K}_{2} \mathrm{O}$ & $\mathrm{TiO}_{2}$ & Others & Purity (\%) \\
\hline $\begin{array}{c}\text { Kawara } \\
\text { limestone }\end{array}$ & 43.22 & 0.00 & 0.03 & 0.02 & 56.08 & 0.28 & 0.00 & 0.00 & 0.00 & 0.02 & 99.66 \\
$\begin{array}{c}\text { Ofunado } \\
\text { limestone } \\
\begin{array}{c}\text { Garou } \\
\text { limestone }\end{array}\end{array}$ & 42.13 & 1.26 & 0.84 & 0.38 & 54.83 & 0.18 & 0.02 & 0.11 & 0.05 & 0.14 & 96.96 \\
\hline
\end{tabular}

In Japan, limestone with white color and high purity like Kawara limestone is called "kansuiseki" [19]. $\mathrm{MgO}, \mathrm{SiO}_{2}, \mathrm{Al}_{2} \mathrm{O}_{3}$ etc. are found in limestone as impurities, and result from quartz, clay mineral, iron oxide mineral, hydroxide mineral, dolomite, etc. [20]. Because of these impurities, limestone presents various colors such as white, light gray, gray, gray black, light brown, etc. [21]. Figure 2 shows samples of natural limestones with different colors. 


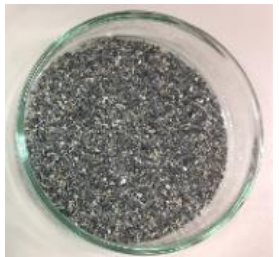

(a)

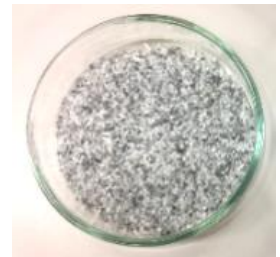

(b)

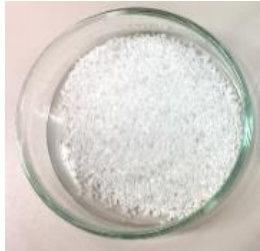

(c)

Figure 2. Samples of (a) Kawara limestone, (b) Ofunato limestone and (c) Garou limestone.

\section{Experimental Analysis}

\subsection{Repeated Hydration Reaction Cycle (Muffle Furnace and TGA-51)}

Figure 3 shows a schematic diagram of the lab-scale experimental unit in an open system. The thermogravimetric analyzer (TGA-51, Shimadzu Corporation, Kyoto, Japan) was used as a reactor, which is connected to an evaporator/condenser with joint valves.

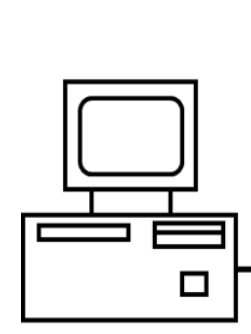

(9)

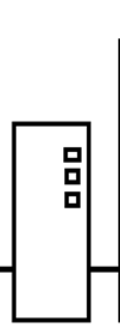

(8)

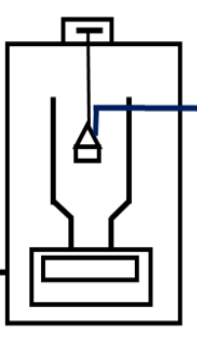

(7)

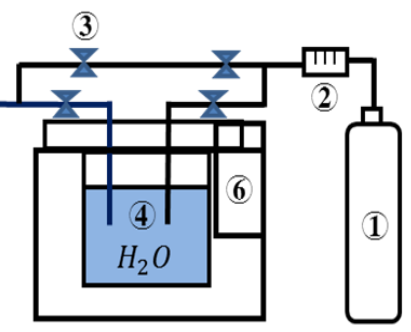

(5)

(a)

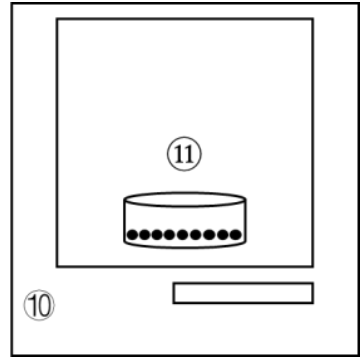

(b)

(1) $N_{2}$ gas (2) Flow meter (3) Valve (4) Evaporator/Condenser

(5) Temperature control bath (6) Heater/Cooler

(7) Thermogravimetric analyzer (TGA-51) 8) Work station (TA-60WS)

(9) Personal computer (10) Muffle furnace (KDF-S90 • FP310) (11) Sample $\mathrm{CaCO}_{3}$

Figure 3. Schematic diagram of experimental unit. (a) TGA-51 (b) muffle furnace. (1).

Ofunato and Kawara limestone samples of $10 \mathrm{~g} / 100 \mathrm{~g}(710-1000 \mu \mathrm{m} \varphi)$ are heated at a rate of $10 \mathrm{~K} / \mathrm{min}$ to $1223 \mathrm{~K}, 1273 \mathrm{~K}, 1373 \mathrm{~K}, 1473 \mathrm{~K}, 1573 \mathrm{~K}$ and kept at that temperature for different periods in a muffle furnace to be decarbonized. After the decarbonization, $10 \mathrm{mg} / 710-1000 \mu \mathrm{m} \varphi \mathrm{CaO}$ particles are placed into the platinum cell of the thermogravimetric analyzer. $\mathrm{N}_{2}$ gas is flowed into the TGA-51 at $70 \mathrm{~mL} / \mathrm{min}$. The temperature is raised to $783 \mathrm{~K}$ at a rate of $10 \mathrm{~K} / \mathrm{min}$. When the temperature reached $783 \mathrm{~K}$, the evaporated water vapor is introduced into TGA-51 at $298 \mathrm{~K}$ with a $\mathrm{N}_{2}$ gas flow $(70 \mathrm{~mL} / \mathrm{min})$. The hydration of $\mathrm{CaO}$ and the dehydration of $\mathrm{Ca}(\mathrm{OH})_{2}$ are repeated at a rate of $2 \mathrm{~K} / \mathrm{min}$ for three cycles between $373 \mathrm{~K}$ and $783 \mathrm{~K}$. The water vapor is consistently maintained under self-pressure at $298 \mathrm{~K}$.

\subsection{Repeated Hydration Reaction Cycle (TGA-51)}

Ten mg $(710-1000 \mu \mathrm{m} \varphi)$ of Ofunato limestone, Kawara limestone and Garou limestone samples are decarbonized under the different conditions without holding time in the TGA-51. Table 2 shows the different decarbonization, hydration and dehydration conditions according to the operation of TGA-51 described in Section 4.1. After decarbonization, $\mathrm{N}_{2}$ gas and water vapor at $298 \mathrm{~K}$ are flowed into the TGA-51 at $70 \mathrm{~mL} / \mathrm{min}$. 
Table 2. Different decarbonization, hydration and dehydration temperature conditions in TGA-51.

\begin{tabular}{|c|c|c|c|c|c|c|}
\hline \multirow{2}{*}{ Samples } & \multirow{2}{*}{ Pre-Heating } & \multicolumn{3}{|c|}{ Decarbonization } & Hydration & Dehydration \\
\hline & & \multicolumn{5}{|c|}{ Temperature } \\
\hline- & $673-683 \mathrm{~K}$ & $1183 \mathrm{~K}$ & $1223 \mathrm{~K}$ & $783 \mathrm{~K}$ & $373 \mathrm{~K}$ & $783 \mathrm{~K}$ \\
\hline $\begin{array}{c}\text { Three } \\
\text { different } \\
\text { kinds of } \mathrm{CaO}\end{array}$ & $7 \mathrm{~K} / \mathrm{min}$ & $3 \mathrm{~K} / \mathrm{min}$ & - & $3 \mathrm{~K} / \mathrm{min}$ & $2 \mathrm{~K} / \mathrm{min}$ & $2 \mathrm{~K} / \mathrm{min}$ \\
\hline $\begin{array}{c}\text { Ofunato } \\
\mathrm{CaO}\end{array}$ & $10 \mathrm{~K} / \mathrm{min}$ & - & $10 \mathrm{~K} / \mathrm{min}$ & $2 \mathrm{~K} / \mathrm{min}$ & $2 \mathrm{~K} / \mathrm{min}$ & $2 \mathrm{~K} / \mathrm{min}$ \\
\hline
\end{tabular}

\section{Results and Discussion}

\subsection{Repeated Hydration Experiments of 3 Different Kinds of $\mathrm{CaO}$}

First of all, in order to compare the conversion and the heat output of three different kinds of $\mathrm{CaO}$, three hydration reaction experiment cycles are performed in the TGA-51 system. Three different kinds of $\mathrm{CaO}$ are decarbonized in the TGA-51 (Section 4.2). Figure 4 shows hydration conversion vs. time and the heat output per $1 \mathrm{~kg}$ of Kawara $\mathrm{CaO}$, Ofunato $\mathrm{CaO}$ and Garou $\mathrm{CaO}$. The heat output is calculated by the reaction rate. From Figure 4, the reaction rates of Kawara $\mathrm{CaO}$ are the highest, and the conversion ratios are over $100 \%$. This is because the conversion ratio is calculated based on the lightest weight of $\mathrm{CaO}$ after decarbonation. When the water vapor is flowed to the thermogravimetry (TGA-51), the weight of $\mathrm{Ca}(\mathrm{OH})_{2}$ become heavier than usual, because of the water vapor adsorbed on Kawara $\mathrm{CaO}$. The reaction rate of Garou $\mathrm{CaO}$ is the lowest among the three different kinds of $\mathrm{CaO}$. It is because that magnesium in Garou $\mathrm{CaO}$ forms a kind of columnar joint texture and inhibit water vapor transferring into $\mathrm{CaO}$ particle [22]. The conversion ratios of Ofunato $\mathrm{CaO}$ are over $94 \%$. It shows that the reactivity of Ofunato $\mathrm{CaO}$ is relatively high, even if there are 3.04\% impurities in Ofunato limestone. In addition, the highest heat output of Kawara $\mathrm{CaO}$ (red circle) is $2.12 \mathrm{~kW} / \mathrm{kg}-\mathrm{CaO}$ at $690 \mathrm{~s}$ and $990 \mathrm{~s}$. Although the heat output of Ofunato $\mathrm{CaO}$ (blue square) is lower than that of Kawara $\mathrm{CaO}$, it is still $1.95 \mathrm{~kW} / \mathrm{kg}-\mathrm{CaO}$ at $510 \mathrm{~s}$. And it is almost constant from $630 \mathrm{~s}$ to $1110 \mathrm{~s}(1.56 \mathrm{~kW} / \mathrm{kg}-\mathrm{CaO})$. The heat output of Garou $\mathrm{CaO}$ (green triangle) is the lowest $(1.51 \mathrm{~kW} / \mathrm{kg}-\mathrm{CaO})$.
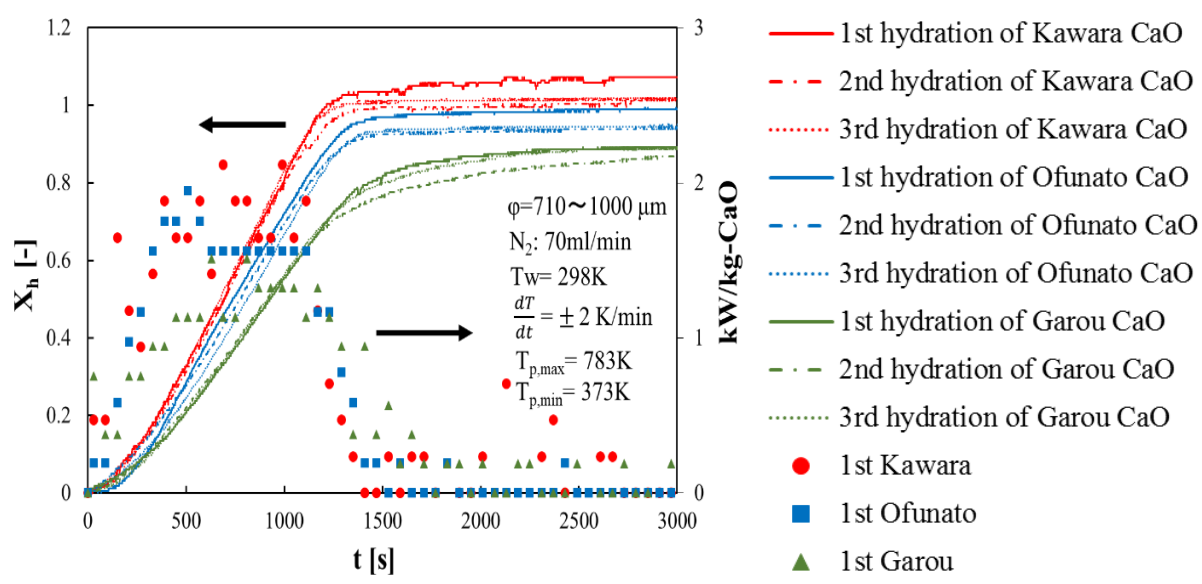

Figure 4. Hydration conversion and the heat output of Kawara $\mathrm{CaO}$, Ofunato $\mathrm{CaO}$ and Garou $\mathrm{CaO}$.

\subsection{Effects of Different Decarbonization Temperature}

Repeated hydration experiments are performed on Ofunato $\mathrm{CaO}$ and Kawara $\mathrm{CaO}$ in the TGA-51 system. Ofunato $\mathrm{CaO}$ and Kawara $\mathrm{CaO}$ are made from $10 \mathrm{~g}$ Ofunato limestone and Kawara limestone decarbonized at $1223 \mathrm{~K}, 1273 \mathrm{~K}, 1373 \mathrm{~K}, 1473 \mathrm{~K}, 1573 \mathrm{~K}$ and kept at that temperature for one hour in a muffle funace (see Section 4.1). Figure 5 shows the 1st hydration conversion (dotted line) and 3rd hydration conversion (full line) of Ofunato $\mathrm{CaO}$ and Kawara $\mathrm{CaO}$ in TGA-51. The reaction rates of 
Ofunato $\mathrm{CaO}$ and Kawara $\mathrm{CaO}$ decarbonized at $1223 \mathrm{~K}$ and $1273 \mathrm{~K}$ have higher reaction characteristics. The temperature dependence of hydration behavior of Ofuanto $\mathrm{CaO}$ is higher than that of Kawara $\mathrm{CaO}$. The conversion ratios of Ofunato $\mathrm{CaO}$ decarbonized at $1573 \mathrm{~K}$ lowed to $10 \%$ drastically. It seems that Ofunato $\mathrm{CaO}$ decarbonized at $1573 \mathrm{~K}$ loses its hydration reactivity.

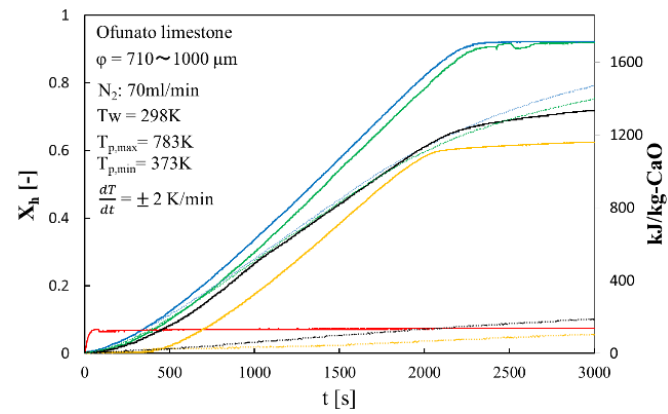

(a)

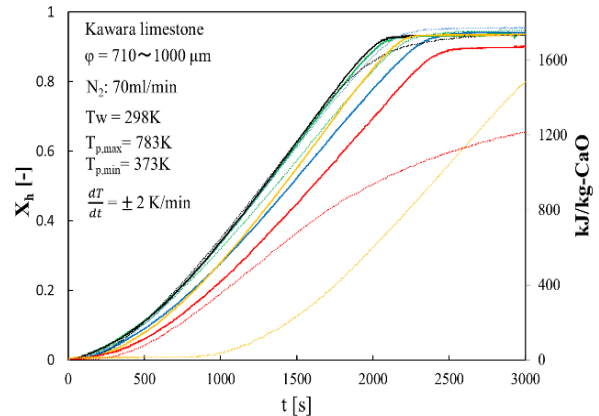

(b)

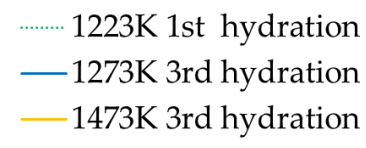

Figure 5. Hydration conversion after decarbonization in muffle furnace. (b) Kawara $\mathrm{CaO}$.

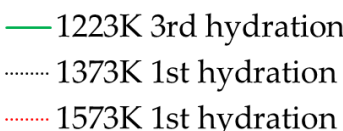

........ 1573K 1st hydration
1273K 1st hydration
$-1373 \mathrm{~K}$ 3rd hydration
$-1573 \mathrm{~K}$ 3rd hydration

(a) Ofunato $\mathrm{CaO}$

Figure 6 shows the XRD pattern of Ofunato $\mathrm{CaO}$ after decarbonization at $1223 \mathrm{~K}, 1273 \mathrm{~K}$ and $1573 \mathrm{~K}(\mathrm{dT} / \mathrm{dt}=10 \mathrm{~K} / \mathrm{min})$ for one hour in a muffle furnace. During the decarbonization stage, the impurities of $\mathrm{Si}$, Fe and $\mathrm{Al}$ react with $\mathrm{CaO}$ to form new compounds, such as $\mathrm{Ca}_{2} \mathrm{Al}_{2} \mathrm{SiO}_{7}$ (gehlenite), $\mathrm{Ca}_{2} \mathrm{Fe}_{1.28} \mathrm{Al}_{0.72} \mathrm{O}_{5}$ (calcium aluminoferrite), $\mathrm{C}_{2} \mathrm{~S}$ [23], etc. It is considered that the sintering of impurities in Ofunato limestone occurs easier than in Kawara limestone with lower impurities. As shown in the $\mathrm{XRD}$ pattern, $\mathrm{Ca}_{2} \mathrm{Al}_{2} \mathrm{SiO}_{7}$ (gehlenite) is produced by the reaction of $\mathrm{CaO} \cdot \mathrm{Al}_{2} \mathrm{O}_{3} \cdot 2 \mathrm{SiO}_{2}$ (anorthite), $\mathrm{Al}_{2} \mathrm{O}_{3}$ and $\mathrm{CaO}$ during the decarbonization at $1573 \mathrm{~K}$ [24]. It can be presumed that the reaction starts from the surface of $\mathrm{CaO}$ particle $[25,26]$ and then the gehlenite covers the surface of $\mathrm{CaO}$ particle to make it lose hydration reactivity. From the repeated hydration experiments, it is assumed that the negative effects of impurities on Ofunato $\mathrm{CaO}$ reactivity could be minimized by controlling the decarbonization temperature and time and the desirable decarbonization conditions can provide the high hydration reaction characteristics even if natural limestone such as Ofunato $\mathrm{CaO}$ containing some impurities.
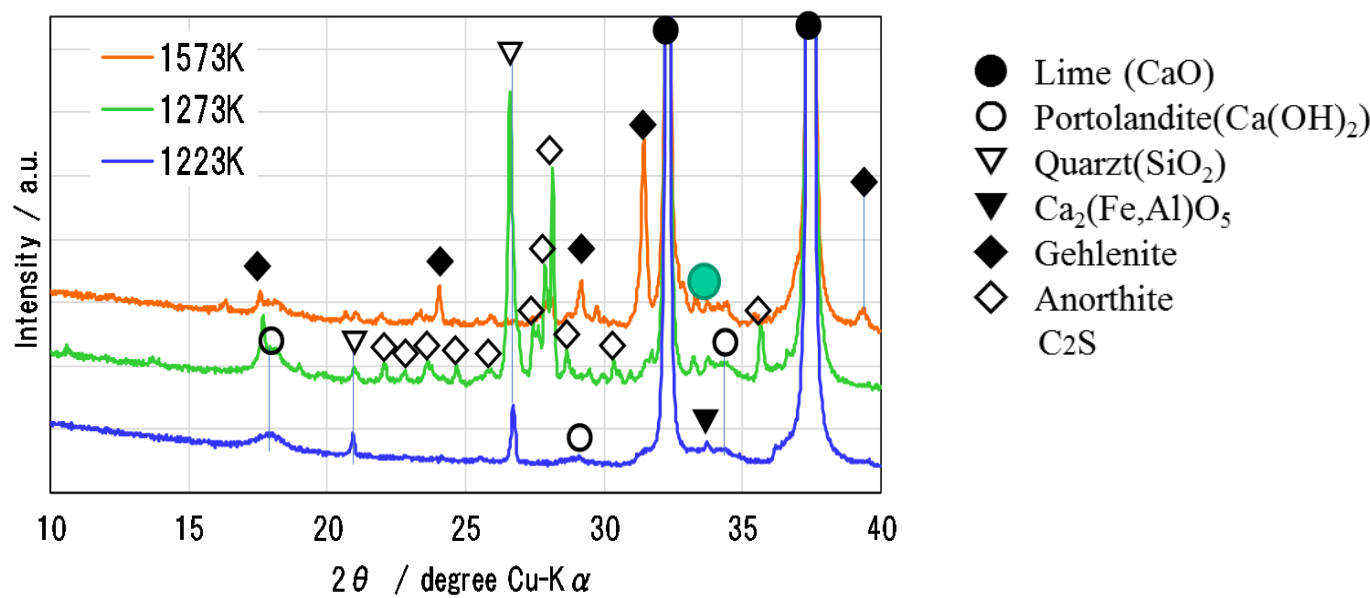

Figure 6. XRD pattern of Ofunato $\mathrm{CaO}$ after decarbonization at $1223 \mathrm{~K}, 1273 \mathrm{~K}$ and $1573 \mathrm{~K}$. 
Table 3 shows the specific surface area and the mean pore diameter of Ofunato $\mathrm{CaO}$ after decarbonization at $1273 \mathrm{~K}$ and $1573 \mathrm{~K}$ in a muffle furnace. The specific surface area and the mean pore diameter decarbonized at $1573 \mathrm{~K}$ is smaller than those at $1273 \mathrm{~K}$. This is probably because that the compounds adhered to the surface of the $\mathrm{CaO}$ particle made specific surface area of $\mathrm{CaO}$ particle smaller. These physical property changes can support the hydration reactivity decrease of Ofunato $\mathrm{CaO}$.

Table 3. Specific surface area and mean pore diameter of Ofunato $\mathrm{CaO}$ after decarbonization at $1273 \mathrm{~K}$ and $1573 \mathrm{~K}$ in muffle furnace.

\begin{tabular}{ccc}
\hline Sample & \multicolumn{2}{c}{ Ofunato CaO } \\
\hline Heat treatment temperature (K) & 1273 & 1573 \\
Specific surface area $\left(\mathrm{m}^{2} / \mathbf{g}\right)$ & 3.31 & 1.11 \\
Mean pore diameter $(\mathbf{4 V / A )}(\mathbf{n m})$ & 28.41 & 16.95 \\
\hline
\end{tabular}

\subsection{Effects of Decarbonization Conditions}

Repeated hydration experiments are performed on Kawara $\mathrm{CaO}$ and Ofunato $\mathrm{CaO}$ in the TGA-51 system. Kawara $\mathrm{CaO}$ and Ofunato $\mathrm{CaO}$ are made from $100 \mathrm{~g}$ Ofunato limestone and Kawara limestone decarbonized at different decarbonization temperatures and holding time in a muffle furnace (see Section 4.1). Figure 7 shows the hydration conversion over two cycles of Ofunato $\mathrm{CaO}$ and Kawara $\mathrm{CaO}$. From Figure 7, Ofunato $\mathrm{CaO}$ has the highest reactivity after decarbonization at $1223 \mathrm{~K}$ for $5 \mathrm{~h}$. Additionally, comparing the first hydration reaction rates of Ofunato $\mathrm{CaO}$ and Kawara $\mathrm{CaO}$, the reaction rate of Ofunato is much lower than Kawara $\mathrm{CaO}$. However, the 2nd hydration reaction rates of Ofunato $\mathrm{CaO}$ become higher than 1st hydration reaction rates. It is hypothesized that the reactivity of Ofunato $\mathrm{CaO}$ can be enhanced by hydration/dehydration repetition [27,28].

Figure 8 shows the hydration conversion of Ofunato $\mathrm{CaO}$ in TGA-51 after decarbonization at $1223 \mathrm{~K}$ for $5 \mathrm{~h}$ in a muffle furnace (described in Section 4.1). Figure 9 shows the hydration conversion changes of Ofunato $\mathrm{CaO}$ after decarbonization at $1223 \mathrm{~K}$ in TGA-51 (see Section 4.2). Figure 8, it shows that 1st hydration conversion of Ofunato $\mathrm{CaO}$ decarbonized at $1223 \mathrm{~K}$ for $5 \mathrm{~h}$ in a muffle furnace is lower. The conversion ratio at $3000 \mathrm{~s}$ is only $20.9 \%$. However, after $8000 \mathrm{~s}$, the conversion ratio increased and finally reached up to $86 \%$.

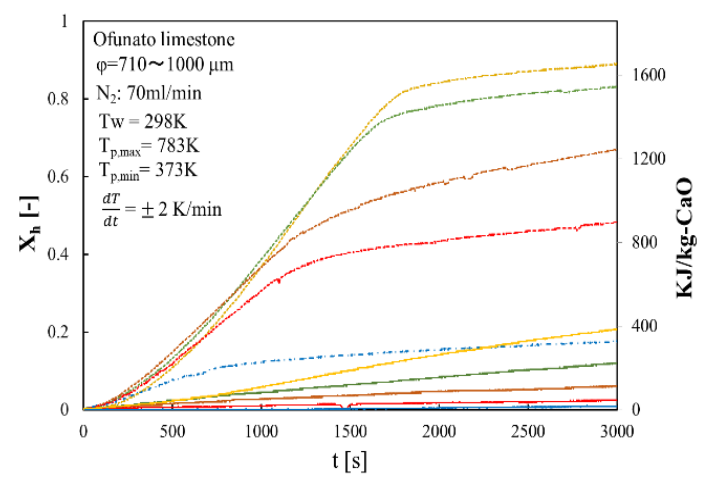

(a)

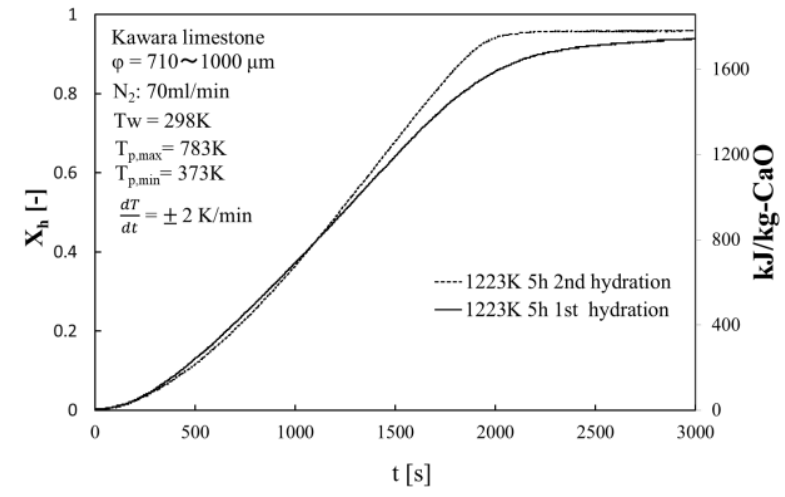

(b)

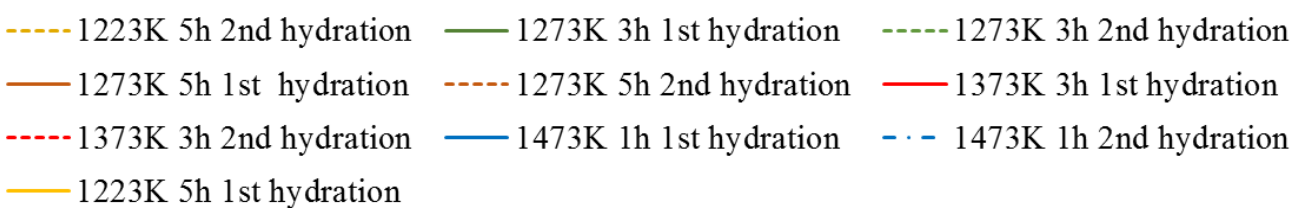

Figure 7. Hydration conversion (a) Ofunato $\mathrm{CaO}$ (b) Kawara $\mathrm{CaO}$. 


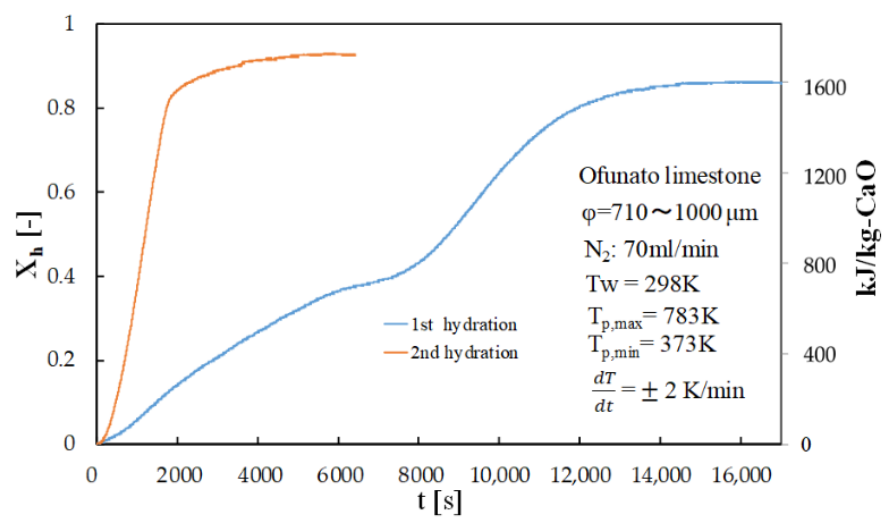

Figure 8. Hydration conversion of Ofunato $\mathrm{CaO}$ in TGA-51 after decarbonization at $1223 \mathrm{~K}$ for $5 \mathrm{~h}$ in muffle furnace.

The conversion ratio of Ofunato $\mathrm{CaO}$ after decarbonization in the TGA-51 is $91.1 \%$ at $3000 \mathrm{~s}$ as seen in Figure 9.

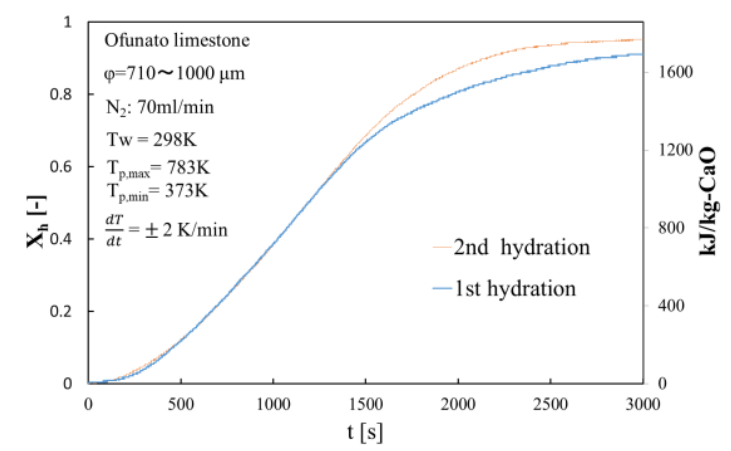

Figure 9. Hydration conversion of Ofunato $\mathrm{CaO}$ after decarbonization at $1223 \mathrm{~K}$ in TGA-51.

In order to evaluate the reactivity of Ofunato $\mathrm{CaO}$, we did 5-cycle repeated hydration reaction experiments in the TGA-51. Ofunato $\mathrm{CaO}$ is made from $100 \mathrm{~g}$ Ofunato limestone decarbonized at $1223 \mathrm{~K}$ for $5 \mathrm{~h}$ in a muffle furnace (see Section 4.1). Figure 10 shows the hydration conversion and the heat output per $1 \mathrm{~kg}$ of Ofunato $\mathrm{CaO}$. Ofunato $\mathrm{CaO}$ have the high reactivity after 2 nd hydration reaction. The hydration reaction rate of Ofunato $\mathrm{CaO}$ increased with the repetition of the hydration/dehydration reactions. Meanwhile, the 5 th hydration conversion ratio of Ofunato $\mathrm{CaO}$ is $95.9 \%$. As shown in Figure 10, the heat output of Ofunato $\mathrm{CaO}$ is stable from $870 \mathrm{~s}$ to $1710 \mathrm{~s}$ and is over $1.11 \mathrm{~kW} / \mathrm{kg}-\mathrm{CaO}$ after 2 nd hydration reaction. The maximum heat outputs of Ofunato $\mathrm{CaO}$ are about $1.29 \mathrm{~kW} / \mathrm{kg}-\mathrm{CaO}$ at $1410 \mathrm{~s}$ and $1470 \mathrm{~s}$ during the 5th hydration reaction. 

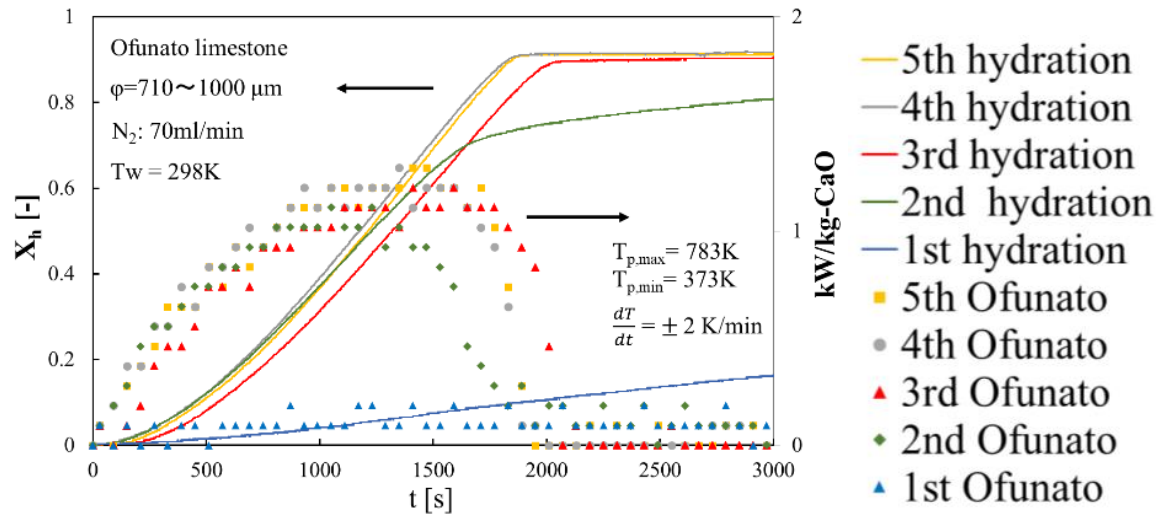

Figure 10. Hydration conversion and the heat output per $1 \mathrm{~kg}$ of Ofunato $\mathrm{CaO}$ in TGA-51 after decarbonization at $1223 \mathrm{~K}$ for $5 \mathrm{~h}$ in muffle furnace.

Figure 11 shows the dehydration conversion of Ofunato $\mathrm{CaO}$ after decarbonization in a muffle furnace. The 1st dehydration conversion ratio is lowest. This is becasuse that reactivity of Ofunato $\mathrm{Ca}(\mathrm{OH})_{2}$ is relatively low during the 1 st dehydration reaction. After the 2 nd dehydration reaction, the reactivity of Ofunato $\mathrm{Ca}(\mathrm{OH})_{2}$ was increased by hydration/dehydration repetition. Figure 12 shows the heat storage and heat release per $1 \mathrm{~kg}$ of Ofunato $\mathrm{CaO}$ in the TGA-51 system. The heat storage and heat release of Ofunato $\mathrm{CaO} / \mathrm{Ca}(\mathrm{OH})_{2}$ are relatively low during the 1st hydation/dehydration, but after a 2nd dehydration reaction, the heat storage and heat release of Ofunato $\mathrm{CaO} / \mathrm{Ca}(\mathrm{OH})_{2}$ becomes stable $(1700 \mathrm{~kJ} / \mathrm{kg}-\mathrm{CaO})$.

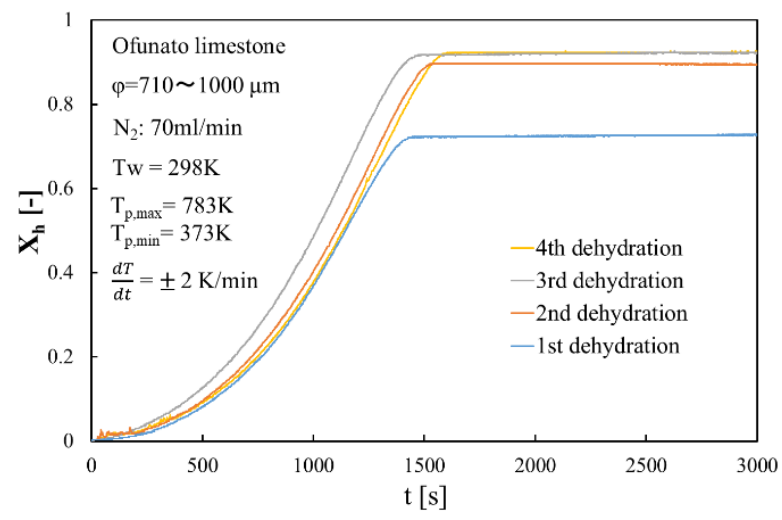

Figure 11. Dehydration conversion of Ofunato $\mathrm{CaO}$ in TGA-51 after decarbonization at $1223 \mathrm{~K}$ for $5 \mathrm{~h}$ in muffle furnace.

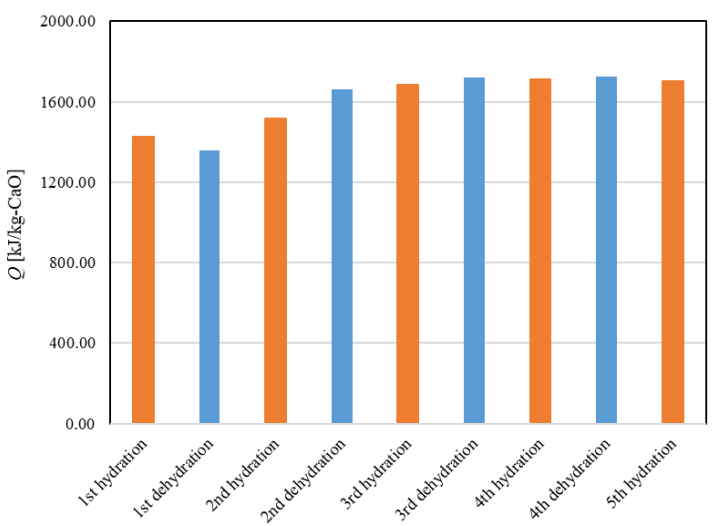

Figure 12. The heat storage and the heat release per $1 \mathrm{~kg}$ of Ofunato $\mathrm{CaO}$ in TGA-51. 


\subsection{Crystal Grain Structure}

Figure 13a-c show $5 \mu \mathrm{m}$ SEM images of Ofunato $\mathrm{CaO}$ after decarbonization in a muffle furnace, Ofunato $\mathrm{Ca}(\mathrm{OH})_{2}$ after the 1st hydration reaction and Ofunato $\mathrm{CaO}$ after 1st dehydration reaction in the TGA-51 (Section 4.1), respectively. As shown in figures a, b and c, the $\mathrm{CaO}$ particles are composed of uniform cocoon-shaped crystal grains. The uniform porous structure can promote the diffusion of water vapor into $\mathrm{CaO}$ particles. From pictures a to $\mathrm{c}$, it is inferred that the pore size becomes large.

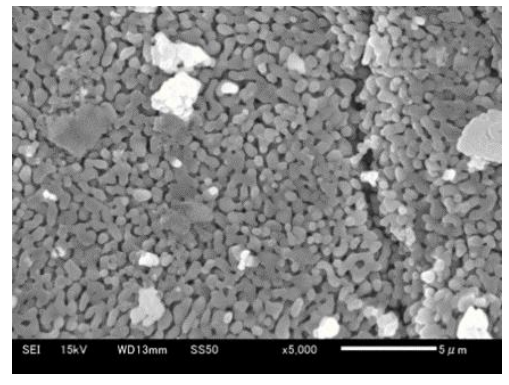

(a)

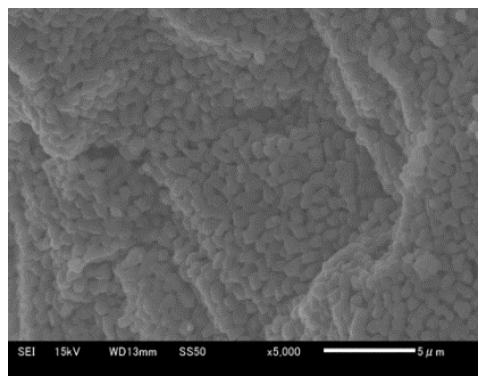

(b)

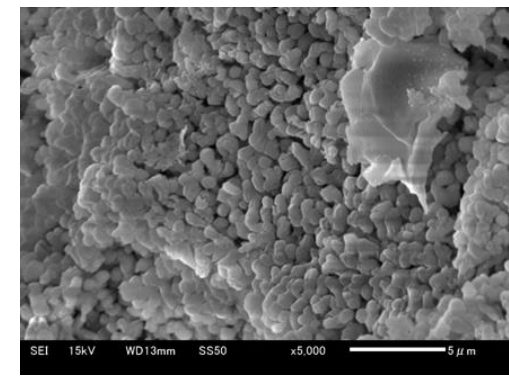

(c)

Figure 13. SEM images of 710-1000 $\mu \mathrm{m} \varphi\left(\right.$ a) Ofunato $\mathrm{CaO},(\mathbf{b})$ Ofunato $\mathrm{Ca}(\mathrm{OH})_{2}$ after 1st hydration reaction, (c) Ofunato $\mathrm{CaO}$ after 1st dehydration reaction after decarbonization at $1223 \mathrm{~K}$ for $5 \mathrm{~h}$ in muffle furnace.

Figure 14a-c show $5 \mu \mathrm{m}$ SEM images of Ofunato $\mathrm{CaO}$ after decarbonization in the TGA-51, Ofunato $\mathrm{Ca}(\mathrm{OH})_{2}$ after the 1st hydration reaction and Ofunato $\mathrm{CaO}$ after the 1 st dehydration reaction in the TGA-51 (Section 4.2). It is shown that the $\mathrm{CaO}$ particles display a plurality of small, heterogeneous block structures. Meanwhile, there are some cracks in the $\mathrm{CaO}$ particles. From pictures $\mathrm{d}$ to $\mathrm{f}$, it could be seen that the block shaped particles increase. Comparing pictured 13a and 14d, it can be considered that more cracks in Ofunato $\mathrm{CaO}$ after decarbonization in the TGA-51 make it easier for water vapor to diffuse into $\mathrm{CaO}$ particles than the pores in Ofunato $\mathrm{CaO}$ after decarbonization in a muffle furnace.

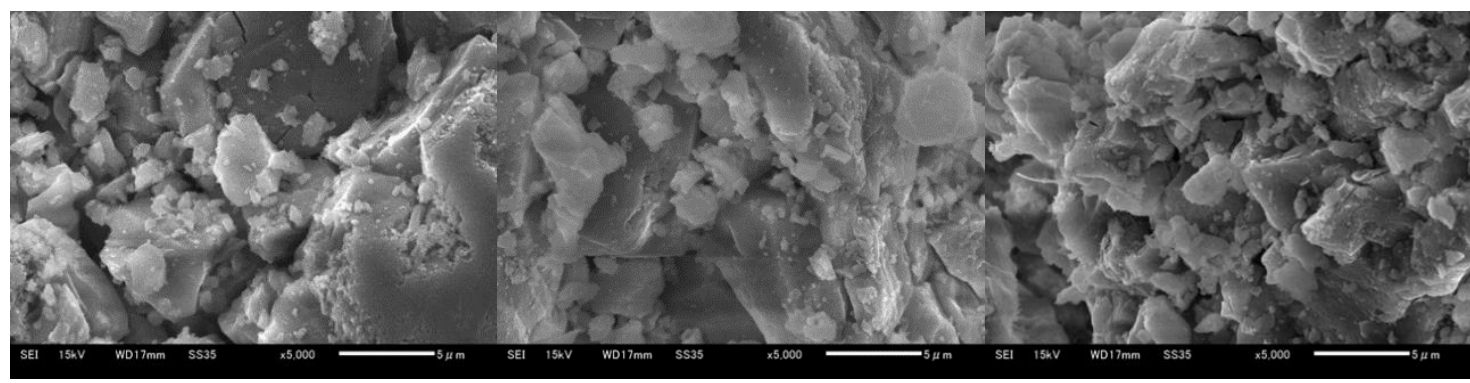

(a)

(b)

(c)

Figure 14. SEM images of 710-1000 $\mu \mathrm{m} \varphi$ (a) Ofunato $\mathrm{CaO}$, (b) Ofunato $\mathrm{Ca}(\mathrm{OH})_{2}$ after 1st hydration reaction, (c) Ofunato $\mathrm{CaO}$ after 1st dehydration reaction after decarbonization without keeping time in TGA-51.

Table 4 shows the specific surface area of Ofunato $\mathrm{CaO}$ after decarbonization at $1223 \mathrm{~K}$ for $5 \mathrm{~h}$ in a muffle furnace and Ofunato $\mathrm{Ca}(\mathrm{OH})_{2}$ after the 1st hydration reaction. As shown in Figure 13 and Table 4, the specific surface area of Ofunato particles becomes large after the 1st hydration reaction. It is hypothesized that the pores are small after decarbonization in the muffle furnace, thus water vapor cannot smoothly diffuse into the $\mathrm{CaO}$ particles, and it can be considered that the $\mathrm{CaO}$ particle bed in the muffle furnace has an important impact on the heat transfer. After the 1st hydration reaction, the pores become large and the reactivity of Ofunato $\mathrm{CaO}$ improves. 
Table 4. Specific surface area of Ofunato $\mathrm{CaO}$ and Ofunato $\mathrm{Ca}(\mathrm{OH})_{2}$ after decarbonization at $1223 \mathrm{~K}$ for $5 \mathrm{~h}$ in a muffle furnace.

\begin{tabular}{ccc}
\hline Sample & Ofunato $\mathrm{CaO}$ & Ofunato $\mathrm{Ca}(\mathrm{OH})_{2}$ \\
\hline Heat treatment temperature $(\mathrm{K})$ & $1223 \mathrm{~K}$ & $1223 \mathrm{~K}$ \\
Specific surface area $\left(\mathrm{m}^{2} / \mathrm{g}\right)$ & 6.69 & 12.20 \\
\hline
\end{tabular}

\subsection{Effects of Impurities in Ofunato $\mathrm{CaO}$}

After decarbonization in the muffle furnace (Section 4.1), Ofunato $\mathrm{CaO}$ has some white particles and black particles, as shown in Figure 15. It is hypothesized that the composition of the white particles and black particles is different. Therefore, the elements in Ofunato $\mathrm{Ca}(\mathrm{OH})_{2}$ white particles and black particles are identified by Energy Dispersive X-ray Spectroscopy, as shown in Tables 5 and 6. From Table 5, the total mass of impurities, like $\mathrm{Mg}$, $\mathrm{Al}$, $\mathrm{Si}$ and $\mathrm{Fe}$, is $1.93 \%$. It could be seen that Ofunato $\mathrm{CaO}$ (white particles) can react fully with water vapor without any observable effect of the impurities. On the other hand, the total mass of impurities in Ofunato $\mathrm{Ca}(\mathrm{OH})_{2}$ black particles is $26.97 \%$, as shown in Table 6. Figure 16 shows a picture of black particles (Ofunato $\left.\mathrm{Ca}(\mathrm{OH})_{2}\right)$ after a 4 th hydration reaction in the TGA-51 system.

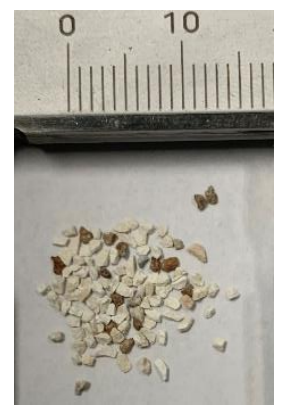

Figure 15. The picture of white particles (Ofunato $\mathrm{CaO}$ ) and black particles (Ofunato $\mathrm{CaO}$ ) after decarbonization at $1223 \mathrm{~K}$ for $5 \mathrm{~h}$ in a muffle furnace.

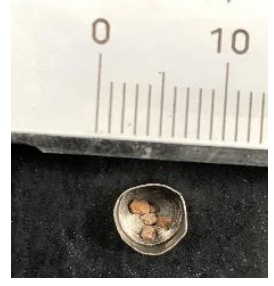

Figure 16. Picture of black particles of Ofunato $\left.\mathrm{Ca}(\mathrm{OH})_{2}\right)$ after a 4 th hydration in the TGA-51 system.

Table 5. Identified elements in Ofunato $\mathrm{Ca}(\mathrm{OH})_{2}$ (white particles) after the 1st hydration in the TGA-51 system and decarbonization in a muffle furnace (measured by Energy Dispersive X-ray Spectroscopy).

\begin{tabular}{cccccccc}
\hline \multicolumn{7}{c}{ Fitting Coefficient: 0.69 } \\
\hline Element & $\mathbf{( k e V )}$ & Mass\% & Error\% & $\mathbf{M o l \%}$ & Compound & Compound Mass\% & K \\
\hline $\mathrm{Mg} \mathrm{K}$ & 1.25 & 0.14 & 3.20 & 0.33 & $\mathrm{MgO}$ & 0.24 & 0.11 \\
$\mathrm{Fe} \mathrm{K}$ & 6.40 & 0.96 & 15.96 & 1.04 & $\mathrm{Fe}_{3} \mathrm{O}_{4}$ & 1.33 & 1.13 \\
$\mathrm{Al} \mathrm{K}$ & 1.49 & 0.16 & 3.50 & 0.16 & $\mathrm{Al}_{2} \mathrm{O}_{3}$ & 0.30 & 0.15 \\
$\mathrm{Si} \mathrm{K}$ & 1.74 & 0.67 & 4.16 & 1.35 & $\mathrm{SiO}_{2}$ & 1.44 & 0.74 \\
$\mathrm{Ca} \mathrm{K}$ & 3.69 & 69.10 & 5.34 & 97.11 & $\mathrm{CaO}$ & 96.69 & 97.88 \\
$\mathrm{O}$ & - & 28.96 & - & - & - & - & - \\
Total & - & 100.00 & - & 100.00 & - & 100.00 & - \\
\hline
\end{tabular}


Table 6. Identified elements in Ofunato $\mathrm{Ca}(\mathrm{OH})_{2}$ (black particles) after a 1st hydration in the TGA-51 system and decarbonization in a muffle furnace (measured by Energy Dispersive X-ray Spectroscopy).

\begin{tabular}{cccccccc}
\hline \multicolumn{7}{c}{ Fitting Coefficient: 0.69 } \\
\hline Element & $\mathbf{( k e V )}$ & Mass\% & Error\% & $\mathbf{M o l \%}$ & Compound & Compound Mass\% & K \\
\hline $\mathrm{Mg} \mathrm{K}$ & 1.25 & 2.40 & 2.50 & 6.06 & $\mathrm{MgO}$ & 3.98 & 2.56 \\
$\mathrm{Fe} \mathrm{K}$ & 6.40 & 6.26 & 12.82 & 7.40 & $\mathrm{Fe}_{2} \mathrm{O}_{3}$ & 8.66 & 9.71 \\
$\mathrm{Al} \mathrm{K}$ & 1.49 & 8.09 & 2.82 & 9.21 & $\mathrm{Al}_{2} \mathrm{O}_{3}$ & 15.29 & 9.84 \\
$\mathrm{Si} \mathrm{K}$ & 1.74 & 10.22 & 3.62 & 22.36 & $\mathrm{SiO}_{2}$ & 21.87 & 13.64 \\
$\mathrm{Ca} \mathrm{K}$ & 3.69 & 35.88 & 4.49 & 54.97 & $\mathrm{CaO}$ & 50.20 & 64.24 \\
$\mathrm{O}$ & - & 37.14 & - & - & - & - & - \\
Total & - & 100.00 & - & 100.00 & - & 100.00 & - \\
\hline
\end{tabular}

The mass of impurities $\left(\mathrm{M}_{\mathrm{im}}\right)$ in Ofunato limestone was calculated using Equation (3):

$$
\mathrm{M}_{\mathrm{total}}=\mathrm{M}_{\mathrm{white}} \times\left(1-\mathrm{M}_{\mathrm{im}}\right)+\mathrm{M}_{\text {black }} \times \mathrm{M}_{\mathrm{im}}
$$

where $\mathrm{M}_{\text {total }}$ denotes chemical compositions of impurities in Table $1, \mathrm{M}_{\mathrm{white}}$ denotes the chemical compositions of white particles in Table $5, \mathrm{M}_{\text {black }}$ denotes the chemical compositions of black particles in Table 6. The mass of impurities in Ofunato limestone is calculated as $4.43 \%$. It could be seen that even if Ofunato limestone contains some impurities $(4.43 \%)$, it can still be utilized as a raw material for chemical heat pumps.

Figure 17 shows the hydration conversion of white particles (Ofunato $\mathrm{CaO}$ ) and black particles (Ofunato $\mathrm{CaO}$ ) in the TGA-51 system after decarbonization at $1223 \mathrm{~K}$ for $5 \mathrm{~h}$ in a muffle furnace (Section 4.1). The 1st, 2nd, 3rd and 4th hydration conversion ratios of black particles are only about $0.64 \%, 1.93 \%, 2.41 \%$ and $1.81 \%$, respectively. In contrast, the 2 nd hydration conversion ratio of white particles is $92.8 \%$. Although black particles contain more than $70 \%$ of $\mathrm{CaO}$, it could hardly react with water during four cycles of repeated hydration reactions. It is possible that new compounds, such as $\mathrm{CaO} \cdot \mathrm{Al}_{2} \mathrm{O}_{3} \cdot 2 \mathrm{SiO}_{2}$, would adhere to the surface of the $\mathrm{CaO}$ particles and prevent the water vapor from diffusing into the $\mathrm{CaO}$ particles.

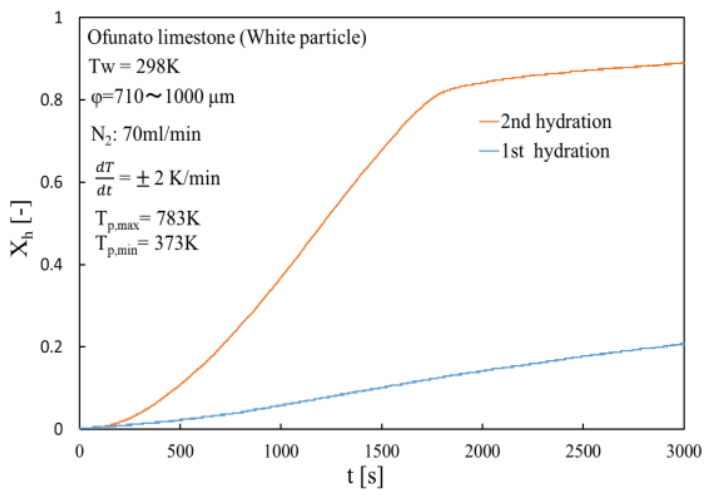

(a)

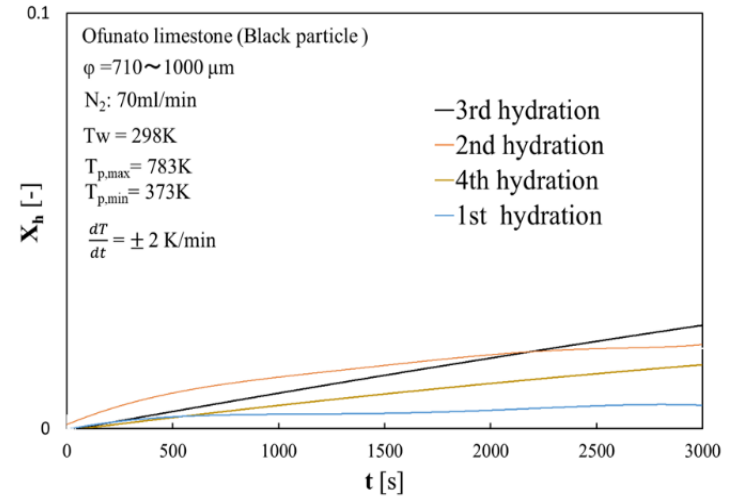

(b)

Figure 17. Hydration conversion in TGA-51 system after decarbonization at $1223 \mathrm{~K}$ for $5 \mathrm{~h}$ in a muffle furnace. (a) white particle (Ofunato $\mathrm{CaO}$ ) (b) black particle (Ofunato $\mathrm{CaO}$ ).

\section{Conclusions}

In this study, in order to evaluate the potential of Ofunato limestone as a chemical heat pump material, we compared Ofunato limestone with Kawara limestone and Garou limestone by some hydration reaction experiments, and evaluated XRD, specific surface area, mean pore diameter, etc. The conclusions are as follows: 
- The high temperature sintering of impurities in Ofunato limestone occurs easier than that in Kawara limestone with lower impurities.

- In the first hydration reaction, the reaction rate of Ofunato $\mathrm{CaO}$ is relatively low. However, the reactivity of Ofunato $\mathrm{CaO}$ could be improved by repeated hydration reaction experiments.

- For practical development of a chemical heat pump, it is viable to use cheaper Ofunato limestone instead of high quality "kansuiseki" (Kawara limestone), which is more expensive.

- The impurities adhered to the surface of the $\mathrm{CaO}$ particles make the specific surface area of $\mathrm{CaO}$ particles smaller, which could inhibit the hydration reactions of the $\mathrm{CaO}$ particles.

- The adverse effects of impurities on the hydration characteristics can be minimalized by controlling the decarbonization temperature and holding time.

Taken together, these results show that Ofunato limestone including impurities can be utilized as a raw material for chemical heat pumps.

Author Contributions: L.L. performed the experiments, did data analysis and wrote the original manuscript. H.O. leaded the program, conceived and designed the experiments. T.I. performed the XRD measurement, analyzed the test results and helped discussion. M.U. and M.I. prepared the samples and BET surface area analysis. All the authors revised and proofread the manuscript. All authors have agreed to the published version of the manuscript.

Funding: This research was funded by Ogura Laboratory, Chiba University and the Central Research Laboratory, Taiheiyo Cement Corporation.

Conflicts of Interest: The authors declare no conflict of interest.

\section{References}

1. Ogura, H.; Yamamoto, T.; Kage, H. Efficiencies of $\mathrm{CaO} / \mathrm{H}_{2} \mathrm{O} / \mathrm{Ca}(\mathrm{OH})_{2}$ chemical heat pump for heat storing and heating/cooling. Energy 2003, 28, 1479-1493. [CrossRef]

2. Ogura, H.; Hamaguchi, N.; Kage, H.; Mujumdar, A.S. Energy and cost estimation for application of chemical heat pump dryer to industrial ceramics drying. Dry. Technol. 2004, 22, 307-323. [CrossRef]

3. Ogura, H.; Saigusa, A.; Shimadu, T. Fundamental experiments for independent heating/cooling system driven by solar energy using $\mathrm{CaSO}_{4} / \mathrm{CaSO}_{4} \cdot 1 / 2 \mathrm{H}_{2} \mathrm{O}$ chemical heat pump. In Proceedings of the Japan Solar Energy Society 2013, Naha, Japan, 28-29 November 2013; p. 122.

4. Ogura, H.; Haba, Y.; Kobayashi, E.; Ren, Y.; Aoki, R.; Hirose, Y. Improvement of Solar Chemical Heat Pump Performance for Refrigeration/Cooling/Heating. In Proceedings of the Grand Renewable Energy 2018, Yokohama, Japan, 17-22 June 2018; p. a90458.

5. Ogura, H.; Fujita, H. Possibility of waste heat recycle utilization for automobiles by chemical heat pump. Trans. JSAE 2016, 47, 579-585. [CrossRef]

6. Kuwata, K.; Esaki, T.; Yasuda, M.; Matsuda, T.; Kobayashi1, N.; Shiren, Y.; Aman, Y. Durability of thermochemical heat storage demonstrated through long-term repetitive $\mathrm{CaCl}_{2} / \mathrm{H}_{2} \mathrm{O}$ reversible reactions. J. Renew. Sustain. Energy 2017, 9, 024102. [CrossRef]

7. Li, J.; Zeng, T.; Kobayashi, N.; Xu, H.; Bai, Y.; Deng, L.; He, Z.; Huang, H. Lithium Hydroxide Reaction for Low Temperature Chemical Heat Storage: Hydration and Dehydration Reaction. Energies 2019, 12, 3741. [CrossRef]

8. Ryo, K.; Junichi, R. Effect of $\mathrm{LiOH}$ Addition on Dehydration Reaction of $\mathrm{Mg}(\mathrm{OH})_{2}$. J. Chem. Eng. Jpn. 2019, 52, 152-158. [CrossRef]

9. Ogura, H.; Haguro, M.; Shibata, Y.; Otsubo, Y. Reaction characteristics of $\mathrm{CaSO}_{4} / \mathrm{CaSO}_{4} \cdot 1 / 2 \mathrm{H}_{2} \mathrm{O}$ reversible reaction for chemical heat pump. J. Chem. Eng. Jpn. 2007, 40, 1252-1256. [CrossRef]

10. Esaki, T.; Kobayashi, N. Reaction rate characteristics of $\mathrm{SrBr}_{2}$ hydration system for chemical heat pump cooling mode. J. Mater. Sci. Chem. Eng. 2016, 4, 106-115. [CrossRef]

11. Esaki, T.; Kuwata, K.; Ichinose, A.; Kobayashi, N. Reaction rate analysis with unreacted-core shell model for chemical heat pump cooling mode with $\mathrm{SrBr}_{2}$ hydration. Jpn. Soc. Mech. Eng. 2017, 83, 16-00439. [CrossRef]

12. Kato, Y.; Yamashita, N.; Kobayashi, K.; Yoshizawa, Y. Kinetic study of the hydration of magnesium oxide for a chemical heat pump. Appl. Therm. Eng. 1996, 16, 853-862. [CrossRef]

13. Tomari, K.; Kishimoto, A.; Toshima, M.; Kansha, Y.; Ishizuka, M.; Tsutsumi, A. Energy saving process for steel heating by using chemical heat pump. J. Jpn. Inst. Energy 2016, 25, 166-167. [CrossRef] 
14. Anzai, T.; Watanabe, T. Present status in lime industry and the future prospects. J. Soc. Inorg. Mater. Jpn. 2016, 23, 49-53.

15. Zhang, H.; Ogura, H. Studies on hydration reaction rates of various size CaO particles for chemical heat storage/pump. J. Chem. Eng. Jpn. 2014, 47, 587-594. [CrossRef]

16. Ogura, H.; Zhang, H.; Umezu, M.; Imai, T.; Ishii, M.; Komatsu, K. Reactivity of Garou Limestone for CaO Chemical Heat Pump/Storage. In Proceedings of the 135th Academic Conference of the Society of Inorganic Materials, Kumamoto, Japan, 16-17 November 2017; p. 45.

17. Kikuchi, Y.; Ishiyama, Y.; Fijita, H.; Hirata, K.; Nakajyo, T.; Ogura, H. Performance enhancement of chemical heat pump unit driven by industrial waste gas heat. J. Jpn. Soc. Energy Resour. 2019, 40, 111-118.

18. Lai, L.; Kikuchi, Y.; Ogura, H.; Imai, T.; Umezu, M.; Ishii, M. Reactivity of Calcium Oxide from Natural Limestones for Chemical Heat Pump/Storage. In Proceedings of the 137th Academic Conference of the Society of Inorganic Materials, Toyobashi, Japan, 15-16 November 2018; p. 37.

19. Yoshimura, T. Characteristic and application of white crystalline limestone (kansuiseki). Limest. Assoc. Jpn. 1997, 56, 69-74.

20. Tagawa, H.; Sugawara, H.; Fujimori, K. Effect of impurities on the shrinkage of limestone during burning. J. Soc. Chem. Ind. Jpn. 1959, 62, 1809-1915. [CrossRef]

21. Limestone Mining Association. Japanese Limestone; Yasuki Printing Office Co., Ltd.: Tokyo, Japan, 1983; pp. 261-262.

22. Zhang, H.; Ogura, H.; Umezu, M.; Imai, T.; Ishii, M. Hydration Reaction characteristics of CaO from various local limestones as chemical heat pump/storage materials. J. Mater. Sci. 2017, 52, 11360-11369. [CrossRef]

23. The Society of Inorganic Materials. Cement.Gypsum.Lime Handbook, 4th ed.; Gihodo Publishing Co., Ltd.: Tokyo, Japan, 1996; pp. 337-339, ISBN 4-7655-0026-8.

24. Wu, X.; Zhou, T.; Chen, Y.; Zhang, Z.; Piao, G.; Kobayashi, N.; Mori, S.; Itaya, Y. Mineral melting behavior of chinese blended coal ash under gasification condition. Asia Pac. J. Chem. Eng. 2011, 6, 220-230. [CrossRef]

25. Sohn, H.Y.; Szekely, J. The effect of reaction order in non-catalytic gas-solid reactions. Chem. Eng. Sci. 1972, 27, 763-778. [CrossRef]

26. Sohn, H.Y. The effects of reactant starvation and mass transfer in the rate measurement of fluid-solid reactions with small equilibrium constants. Chem. Eng. Sci. 2004, 59, 4361-4368. [CrossRef]

27. Watanabe, T.; Hayashi, M.; Matsuda, H.; Hasatani, M. Enhancement of reactivity of CaO produced from limestone by means of hydration-dehydration treatment. J. Chem. Eng. Jpn. 1993, 19, 91-98. [CrossRef]

28. Ogura, H.; Abliz, S.; Kage, H. Studies on applicability of scallop material to calcium oxide/calcium chemical heat pump. Fuel Process. Technol. 2004, 85, 1259-1269. [CrossRef] 